\title{
CHINESE MIRROR FROM THE LATE SARMATIAN SITE CHERNY YAR ${ }^{1}$
}

\author{
Lyudmila A. Kraeva
}

Orenburg State Pedagogical University, Orenburg, Russian Federation

\section{Miljana Radivojevic}

McDonald Institute for Archaeological Research, University of Cambridge, Cambridge, United Kingdom

\author{
Irina G. Ravich
}

Metal Research Institute for Conservation, Moscow, Russian Federation

\section{Larisa P. Chernikova}

Institute for Oriental Studies, Russian Academy of Sciences, Moscow, Russian Federation

Iya A. Shuteleva

Bashkir State Pedagogical University, Ufa, Russian Federation

Nikolay B. Shcherbakov

Bashkir State Pedagogical University, Ufa, Russian Federation

Abstract. This paper provides the description and results of interdisciplinary research into the Chinese mirror from the elite Late Sarmatian burial mound Cherny Yar, located in the south of the Orenburg region (oblast) in the southern Urals, and dated by the $2^{\text {nd }}-3^{\text {rd }} \mathrm{cc}$. AD. The mirror was found in a wooden case made of wooden twigs rolled in a spiral. It is a circular disc with a diameter of $17 \mathrm{~cm}$ with a loop-shaped handle in the center, and its outer surface is decorated with a complex ornament and symbols.

We've conducted X-ray fluorescence analysis, optical and scanning electron microscopy with an energydispersive spectrometer, as well as linguistic analysis.

The metallographic examination shows that the mirror was produced by casting in a low-heat-conducting clay mould or a stone mould, while its microstructure was characteristic for cast high-tin bronzes with lead. The object was cast and, most likely, quickly cooled. There are no traces of silver or tin coating on the mirror. The addition of lead was necessary to reduce porosity and improve fluidity, as well as to obtain the desired pattern from the mould.

Both methods of studying microstructure (metallography and electron microscopy) confirm that, when it comes to mirror manufacturing technology, this sample could not be produced in the Sarmatian culture environment, but had analogies in other territories, such as China, in particular. This is also confirmed by a characteristic ornament and the presence of symbols on the mirror.

The inscriptions on the mirror refer to the style of Zhuangshu, to its simplified version-Xiaozhuan. Symbols on the mirror show 12 signs, the so-called earthly branches, which are associated with 12 animals of the annual cycle, some of which are depicted side by side.

Key words: mirror, China, Sarmatians, Southern Urals, X-ray fluorescence analysis, scanning electron microscopy with energy dispersive spectrometer.

Citation. Kraeva L.A., Radivojevic M., Ravich I.G., Chernikova L.P., Shuteleva I.A., Shcherbakov N.B. Chinese Mirror from the Late Sarmatian Site Cherny Yar. Vestnik Volgogradskogo gosudarstvennogo universiteta. Seriya 4, Istoriya. Regionovedenie. Mezhdunarodnye otnosheniya [Science Journal of Volgograd State University. History. Area Studies. International Relations], 2018, vol. 23, no. 3, pp. 176-188. (in Russian). DOI: https://doi.org/10.15688/ jvolsu4.2018.3.16 


\title{
КИТАЙСКОЕ ЗЕРКАЛО ИЗ ПОЗДНЕСАРМАТСКОГО КОМПЛЕКСА «ЧЕРНЫЙ ЯР» ${ }^{1}$
}

\author{
Людмила Анатольевна Краева \\ Оренбургский государственный педагогический университет, г. Оренбург, Российская Федерация
}

\section{Миляна Радивоевич}

Институт археологических исследований Макдональда, Кембриджский университет, г. Кембридж, Великобритания

\section{Ирина Григорьевна Равич}

Государственный научно-исследовательский институт реставрации, г. Москва, Российская Федерация

\section{Лариса Петровна Черникова}

Институт востоковедения РАН, г. Москва, Российская Федерация

\section{Ия Александровна Шутелева}

Башкирский государственный педагогический университет им. М. Акмуллы, г. Уфа, Российская Федерация

\section{Николай Борисович Щербаков}

Башкирский государственный педагогический университет им. М. Акмуллы, г. Уфа, Российская Федерация

Аннотация. Статья посвящена описанию и результатам междисциплинарного исследования китайского зеркала из элитного позднесарматского погребения могильника «Черный Яр». Курганный могильник расположен на юге Оренбургской области в Южном Приуралье, погребение датируется II-III вв. н. э. Зеркало находилось в деревянном футляре, изготовленном из деревянных прутиков, свернутых по спирали. Оно представляло собой круглый диск диаметром 17 см с петлевидной ручкой по центру, его внешнюю поверхность украшал сложный орнамент и иероглифы.

Были проведены рентгенофлуоресцентный анализ и комплекс исследований с помощью оптической и сканирующей электронной микроскопии, а также лингвистический анализ.

Металлографическое исследование показало, что зеркало получено с помощью литья в малотеплопроводную глиняную или каменную форму, а его микроструктура характерна для литых высокооловянных бронз со свинцом. Объект был отлит и, скорее всего, быстро охлажден. Следы серебряного или оловянного покрытия на зеркале отсутствуют. Добавление свинца было необходимо для уменьшения пористости и улучшения жидкотекучести, а также для получения желаемого рисунка в форме.

Оба метода изучения микроструктуры (металлография и электронная микроскопия) подтверждают, что с точки зрения технологии изготовления зеркало не могло быть сделано в среде сарматской культуры, а является изделием китайского производства. Иероглифы и наличие характерного орнамента на зеркале также свидетельствуют об этом.

Надписи на зеркале относятся к стилю чжуаньщу, к его упрощенному варианту - сяочжуань. Иероглифы на зеркале означают 12 знаков, так называемых земных ветвей, которые ассоциируются с 12 животными годового цикла, некоторые из которых изображены рядом.

Л.А. Краевой разработана общая концепция работы, проведены описание и археологический анализ зеркала. Металлографические исследования произведены методом сканирующей электронной микроскопии с использованием энергодисперсионного спектрометра М. Радивоевич, методом рентгенофлуоресцентного анализа - И.Г. Равич. Лингвистический анализ и поиск аналогий осуществлены Л.П. Черниковой, И.А. Шутелевой и Н.Б. Щербаковым.

Ключевые слова: зеркало, Китай, сарматы, Южный Урал, рентгенофлуоресцентный анализ, сканирующая электронная микроскопия с использованием энергодисперсионного спектрометра.

Цитирование. Краева Л. А., Радивоевич М., Равич И. Г., Черникова Л. П., Шутелева И. А., Щербаков Н. Б. Китайское зеркало из позднесарматского комплекса «Черный Яр» // Вестник Волгоградского государственного университета. Серия 4, История. Регионоведение. Международные отношения. - 2018. - Т. 23, № 3. - C. 176-188. -DOI: https://doi.org/10.15688/jvolsu4.2018.3.16 


\section{Введение}

В 2007 г. экспедицией Оренбургского педагогического университета было раскопано два кургана из курганного могильника «Черный Яр» [6; 7; 13].

Курганный могильник «Черный Яр» расположен в Соль-Илецком районе Оренбургской области, в 4 км к востоко-юго-востоку от с. Тамар-Уткуль и в 3,5 км к западо-северозападу от пос. Кумакский, на высоком гребне первой террасы левого берега р. Илек (приток р. Урал). В могильнике на данный момент насчитывается около 70 насыпей, образующих 3 скопления: северо-восточное, центральное и юго-западное, протяженность курганной площадки с юго-запада на северо-восток составляет 1,5 км.

Впервые данный археологический памятник был открыт К.Ф. Смирновым в 1956 г. во время разведочных работ по левобережью р. Илек, им же был исследован один курган в северо-восточной группе, который дал средневековый материал [ 17 , c. $28-31 ; 18$, с. $11-14]$.

В 1983 г. совместным археологическим отрядом ИИЯЛ БФ АН СССР и Башкирского пединститута было исследовано 12 курганов, которые содержали захоронения от ранней бронзы до позднего средневековья [5].

В 1987 г. отрядом Оренбургской археологической экспедиции пединститута был раскопан один курган в северо-восточной группе памятника, относящийся к раннесарматской культуре [16; 14. с. 51-53].

Раскопанные в 2007 г. курганы 50, 42 дали материал позднесарматской культуры, до этого не известный в могильнике $[6 ; 7 ; 13]$.

Курган 42 содержал элитное, частично разграбленное в древности, парное захоронение, которое по погребальному обряду и вещевому комплексу относится к хронологической группе II-III вв. н. э.

Погребение было совершено в обширной квадратной могильной яме, над которой была возведена шатровидная деревянная конструкция из березы и тополя, опирающаяся на вал. Высота насыпи кургана - 1,5 м, диаметр 32 м. Захоронение принадлежало мужчине и женщине, черепа которых носили следы искусственной деформации.
Среди предметов, оставленных грабителями, найдены: керамические сосуды, бронзовый котел, куски мела, оселок, деревянная портупейная бляха, плакированная серебряным листом, бронзовая пряжка, нашивные бляшки из бронзы и золота, инкрустированная в золотую оправу стеклянная подвеска, пряслица, многочисленные фрагменты железных предметов.

В юго-западном углу могилы под осыпью вала на дне могилы (-352 см от 0) находилась in situ группа предметов: стеклянный бальзамарий, куски охры и бронзовое зеркало в футляре.

Футляр был изготовлен из деревянных прутиков (годичных веток кустарника) ${ }^{2}$ толщиной 5 мм, свернутых по спирали (рис. 1,1 ). Прутики крепились между собой с помощью оплетки из радиально расположенных крученых нитей, которые шли от центра к периферии и хорошо сохранились с внутренней стороны, прилегающей к зеркалу. Спиральное плетение - один из самых распространенных видов плетения с древнейших времен [19, с. 107]. К сожалению, из-за неблагоприятных климатических условий дерево плохо сохраняется в местном грунте, однако остатки плетеных изделий изредка встречаются в сарматских захоронениях. Судя по материалам погребений, ранние кочевники Южного Приуралья пользовались плетеными циновками, корзинками, футлярами для зеркал, в том числе сплетенными из травы [1, с. 54], но информация об известных сарматам способах плетения отсутствует.

Зеркало представляло собой круглый диск диаметром 17 см с петлевидной ручкой по центру. Толщина диска 4-5 мм, диаметр ручки 2,2 см, высота ручки-петельки 1 см. Внешнюю поверхность зеркала (со стороны ручки) украшал сложный орнамент. К сожалению, из-за затертости и патины он не весь четко читался, но благодаря наблюдениям под микроскопом (МБС-10) и применению техники сведения рисунка путем калькирования графитом удалось разглядеть большую часть изображений (рис. 1, 2-3).

Центральная круглая в плане петелька зеркала вписана в систему из двух квадратов (внешний квадрат образован двойной линией). Пространство между квадратами заполнено 
Китайское зеркало из позднесарматского комплекса «Черный Яр»
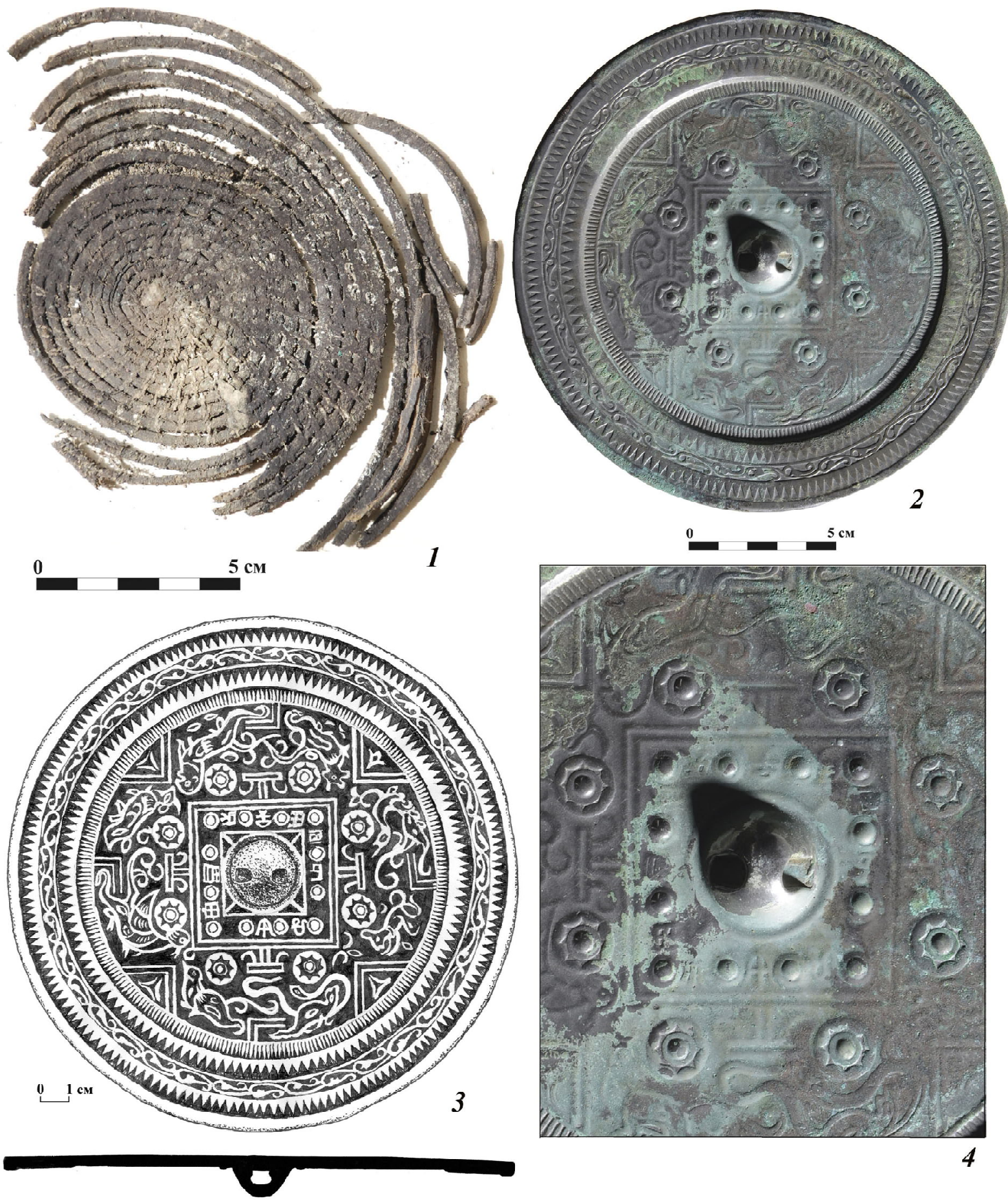

Рис. 1. Футляр и китайское зеркало из курганного могильника «Черный Яр»

Fig. 1. The wooden case and the Chinese mirror from the burial mound Cherny Yar

12 округлыми выступами, между которыми хорошо видны 9 иероглифов, но, видимо, их было 12. Вокруг квадратов находятся 8 круглых рельефных выступов с восьмиарочным декором, перемежающихся с четырьмя Т-образными знаками, которые примыкают к центру каждой стороны внешнего квадрата. Да- лее по кругу шли изображения реальных (птицы, тигра, змеи, зайца) и фантастических животных (дракон?). Изображения существ разделены 8 чередующимися геометрическими фигурами из двойных линий, напоминающими буквы «V» и «L». Они примыкали к сложному орнаментальному поясу, который окружал всю 


\section{ДИАЛОГ «ВОСТОК - ЗАПАД»}

центральную композицию по периметру. Внутренний пояс состоял из коротких радиальных линий, снаружи от него расположены 2 пояса, заполненные треугольными зубчиками и находящимся между ними поясом из ритмического растительного декора. Внешний бортик зеркала был гладким.

Зеркало сохранилось полностью, коррозия проявляется только на поверхности его орнаментированной и лицевой сторон в виде характерных зеленых медных солей, в некоторых участках заметны коричневые пятна закиси меди (куприта), красные в поляризованном свете. На большой площади в центре и по краям орнаментированной стороны про- свечивает металл серебристого цвета, он также проявляется под слоем зеленых солей в отдельных точках лицевой стороны. В центре лицевой стороны виден небольшой круглый участок желтого металла (рис. 2, 1).

На лицевой стороне в некоторых участках сохранились следы от плетеного из древесных прутиков футляра, в котором находилось зеркало. Они заметны в виде выборочного роста зеленых медных солей вдоль концентрических окружностей и прямых линий, пересекающих их в радиальном направлении (рис. 2, 1). Под бинокулярным микроскопом в одном из участков поверхности обнаружены изогнутые при плетении древесные волокна (рис. 2, 2-3).
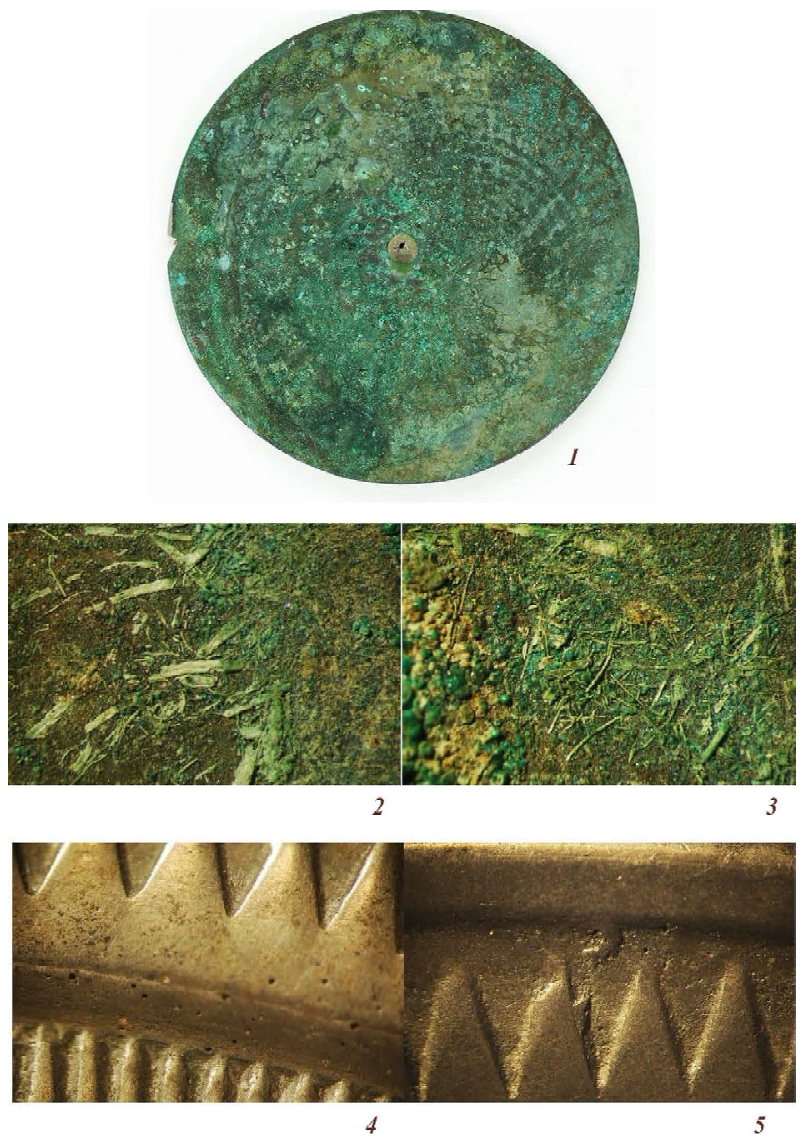

Рис. 2. Особенности коррозии (1-3) и дефекты литья $(4,5)$, заметные на поверхности зеркала из курганного могильника «Черный Яр»:

1 - общий вид корродированной зеркальной поверхности с отпечатками деревянного футляра; 2, 3 - зеркальная поверхность с остатками деревянных волокон в продуктах коррозии; 4 - поры на орнаментированной поверхности зеркала;

5 - натеки металла на орнаментированной поверхности зеркала

Fig. 2. Features of corrosion (1-3) and casting defects $(4,5)$, visible on the surface of the mirror from the burial mound Cherny Yar:

1 - overall view of the corroded mirror surface with the imprints of the wooden case;

2, 3 - mirror surface with the remains of wooden fibers in corrosion products;

4 - pores on the ornamented surface of the mirror; 5 - the flows of metal on the ornamented surface of the mirror 
В центре лицевой стороны рассматриваемого зеркала заметен дефект литья в виде небольшого отверстия (рис. 2, 1), вероятно, связанный с недоливом металла в области центральной выпуклости тыльной стороны. При исследовании под бинокулярным микроскопом на тыльной стороне зеркала обнаружены поры, каверны и затеки металла в неровности и углубления литейной формы (рис. 2 , 4-5), которые при обычном визуальном исследовании не были заметны и не влияли на внешний вид зеркала.

Зеркало является китайским импортом и, судя по орнаментации, относится к типу TLV. Эта разновидность зеркал получила широкое распространение в Китае в эпоху Западной Хань [3, с. 147; 2, с. 59]. Подобные зеркала известны и далеко за пределами Китая: в Южной Сибири [11, с. 39 , рис. 6-7], Фергане [10, с. 100, табл. 25, 1], Южном Приуралье [15, рис. 2, 3], Подонье [3, с. 146-147] и на Нижней Сырдарье [8, с. 234, рис. 160, 34]. Все они происходят из комплексов, датируемых не ранее I в. до н. э. - III в. н. э., причем встречаются как непосредственно китайские зеркала, так и их реплики $[9$, с. 31 ; 12, с. 13].

Анализ иероглифов на зеркале показал, что надписи относятся к стилю Чжуаньшу, к его упрощенному варианту, так называемому сяочжуань («малая печать») ${ }^{3}$.

Вероятно, иероглифы на зеркале, заключенные в квадрат, означают 12 знаков, так называемых «земных ветвей», которые ассоциируются с 12 животными годового цикла, некоторые из которых изображены рядом (хорошо читаются: тигр, заяц, змея, птица, дракон). Аналогичные иероглифические символы и схему их расположения приводит в своей работе Е.В. Завадская [4, c. 185 , табл. IX].

Изображенные на зеркале элементы типичны для зеркал периода Хань: на квадрате Земли в центре - ось Мира, гора Бошань (ручка-петля), окруженная облачным узором, по краю - циклические знаки «двенадцати земных ветвей», перемежающиеся с зернами риса. На белом поле - восемь столпов, соединяющих Небо и Землю, циркули (Небо), угольники (Земля), Т-образные фигуры (знаки плодородия?) и знаки стран света. По кру- гу - узор гор и волн - горизонт (начало Неба) [4, c. 171-172].

\section{Материалы и методы}

Технология изготовления зеркала из комплекса «Черный Яр» была изучена методами металлографического анализа и сканирующей электронной микроскопии с использованием энергодисперсионного спектрометра.

Исследования состава проводились двумя разными методами: 1) методом сканирующей электронной микроскопии с использованием энергодисперсионного спектрометра (SEM-EDS) - M. Радивоевич и А. Франжич (Археологическая лаборатория Вульфсон, Институт археологии Королевского колледжа, г. Лондон); 2) методом рентгенофлуоресцентного анализа - И.Г. Равич (отдел металла ГосНИИР, г. Москва) ${ }^{4}$.

Метод сканирующей электронной микроскопии с использованием энергодисперсионного спектрометра (SEM-EDS). Образец металла из зеркала был вмонтирован в смолу и промаркирован как «ВАЕ 14».

Затем данный образец был отшлифован при помощи абразивов со значениями микро-

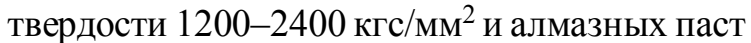
зернистостью 1-2 мкм. Подготовленный образец был помещен в ультразвуковую ванну и после каждого этапа шлифования и полировки промывался этанолом.

После полировки образец был подвергнут микроструктурному анализу при помощи оптического микроскопа. С целью выявления микроструктуры образца был использован хлорид железа $\left(\mathrm{FeCl}_{3}\right)$.

Для дальнейшего проведения исследования под растровым электронным микроскопом с энергодисперсионным спектрометром (SEM-EDS) образец был покрыт углеродом.

Метод рентгенофлуоресиентного анализа. Изучение состава зеркала осуществлялось с помощью прибора фирмы НИТОН. Анализ проводился в области желтого металла в центре лицевой стороны зеркала и в участках серебристого металла на его орнаментированной поверхности, чтобы выявить: не является ли серебристый цвет металла следствием лужения или серебрения. 
Технологию изготовления определяли путем исследования микроструктуры участков желтого и серебристого металла зеркала с помощью металлографии. В таблице 1 суммированы методы и цели анализа микроструктуры, осуществленные с помощью оптической микроскопии с применением поляризованного света и электронной микроскопии.

\section{Анализ}

\section{и результаты исследования}

Металлографическое исследование показало, что зеркало получено с помощью литья в малотеплопроводную глиняную или каменную форму, а его микроструктура характерна для литых высокооловянных бронз со свинцом. Микроструктура хорошо гомогенизирована. После травления на шлифах заметны три фазы: $\alpha$-фаза в виде областей круглой и пластинчатой формы, расположенная на фоне эвтектоида $(\alpha+\delta)$ (рис. 3,1$)$, а также включения свинца. Альфа-фаза ярко-желтая, эвтектоид $(\alpha+\delta)$ серого цвета.

Включения свинца отчетливо проявляются на шлифе в виде многочисленных мелких и неравномерно распределенных крупных глобулей (рис. 3, 2).

В $\alpha$-фазе проявляется дендритная ликвация, вследствие которой ее центр обогащен более высокоплавким компонентом - медью (рис. 4).
Присутствие эвтектоида $(\alpha+\delta)$ говорит о высоком содержании олова, что позднее было также подтверждено и исследованием под электронным микроскопом. Появление видманштеттовых структур в изученной бронзе (рис. 4) говорит о закаливании образца при промежуточных температурах. Это характерно для бронзовых изделий с высоким содержанием оловянистой лигатуры, в том числе и находок римского времени [22, p. 27].

Обогащение серебристых участков оловом связано с процессом избирательной структурной коррозии $\alpha$-фазы (рис. 3,3 ) и уходом из нее меди, $\delta$-фаза эвтектоида, имеющая серебристый цвет, коррозией не затронута. Вследствие этого рассматриваемые участки обогащены оловом (что подтвердил приведенный выше анализ их состава) и имеют серебристый цвет.

Следы серебряного или оловянного покрытия на зеркале отсутствуют.

Явление избирательной коррозии высокооловянных бронз описано в литературе. Поверхность высокооловянных золотистых зеркал, найденных при археологических раскопках, часто становится белой вследствие почвенной коррозии, связанной с переходом в почву ионов меди из структурных составляющих сплава $-\alpha$-фазы и эвтектоида $(\alpha+\delta)$. Сохранение в поверхностном слое серебристой $\delta$-фазы и образование окиси олова в участках $\alpha$-фазы придает зеркалам серебристый цвет [23, p. 349].

Таблииа 1

Методы анализа микроструктуры зеркала из комплекса «Черный Яр»

\begin{tabular}{|c|c|c|}
\hline Инструмент & Цель анализа & Аналити ческие параметры \\
\hline $\begin{array}{l}\text { Поляризационный мик- } \\
\text { роскоп (исследования в } \\
\text { отраженном свете) } \\
\text { (Leica DMLM) }\end{array}$ & $\begin{array}{l}\text { Идентификация примесей и визуальная } \\
\text { характеристика микроструктуры }\end{array}$ & $\begin{array}{l}\text { Поляризационный свет использовался } \\
\text { для изучения примесей в образцах, их } \\
\text { однородности, пористости и включений } \\
\text { (по форме, размеру и однородности). } \\
\text { Микроскоп был оснащен цифровой ка- } \\
\text { мерой Nikon с самым высоким увеличе- } \\
\text { нием в } 500 \text { раз }\end{array}$ \\
\hline $\begin{array}{l}\text { Растровый электронный } \\
\text { микроскоп и энергодис- } \\
\text { персионный спектро- } \\
\text { метр (Superprobe JEOL- } \\
\text { JXA-8600) }\end{array}$ & $\begin{array}{l}\text { 1. Определение фаз и примесей в образ- } \\
\text { цах с использованием электронных изо- } \\
\text { бражений в различных областях (точках } \\
\text { анализа). } \\
\text { 2. Количественный анализ состава на- } \\
\text { блюдаемых фаз (примесей). } \\
\text { 3. Наблюдение взаимосвязей между фа- } \\
\text { зами на основе уровня их атомной кон- } \\
\text { трастности }\end{array}$ & $\begin{array}{l}\text { Проводилось исследование изображений } \\
\text { при помощи энергодисперсионного } \\
\text { спектрометра (BSE). Параметры работы } \\
\text { спектрометра составляли ускоренно рас- } \\
\text { тущее напряжении до } 20 \text { кВ, в простое } \\
\text { (остановке) 35-40\% и рабочем расстоя- } \\
\text { нии } 10 \text { мм. Все данные представлены в } \\
\text { виде элементов, упорядоченных по весу } \\
\text { в \% }\end{array}$ \\
\hline
\end{tabular}



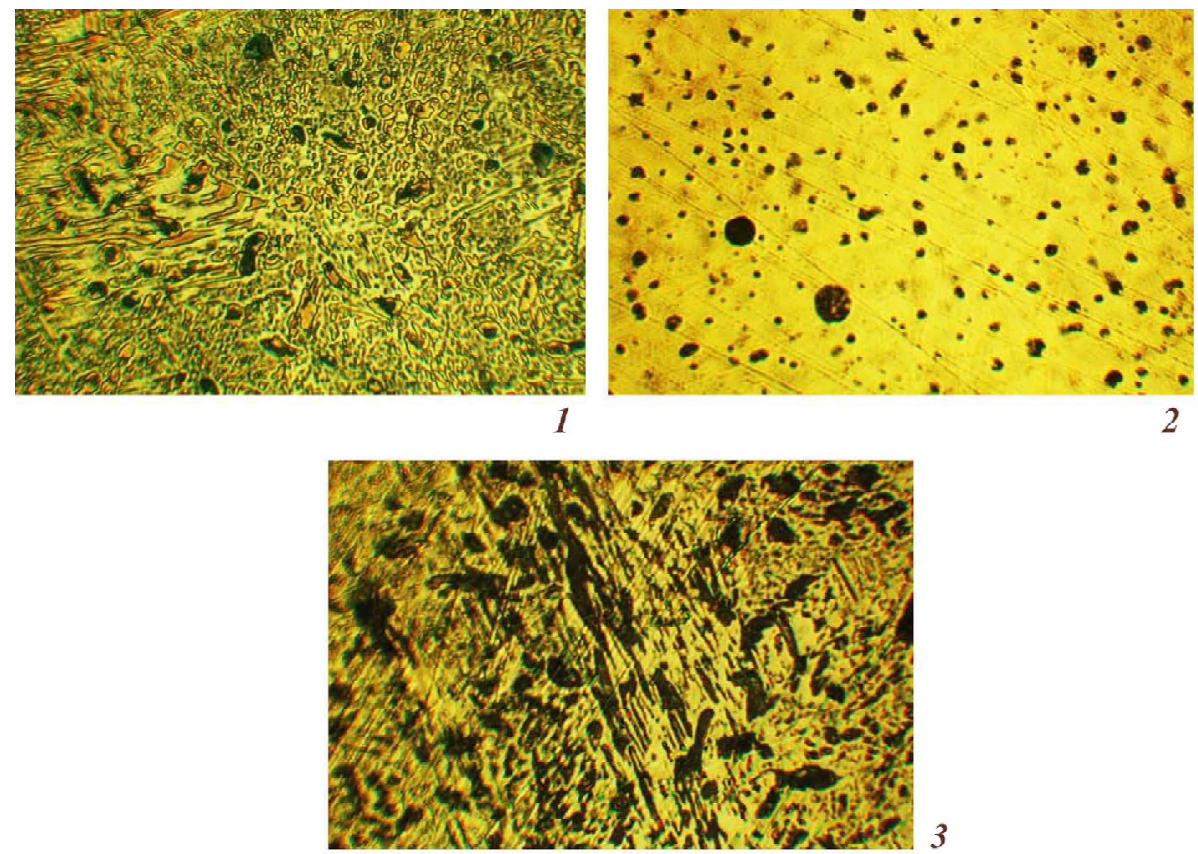

Рис. 3. Микроструктуры зеркала из могильника «Черный Яр». ×450:

1 - микроструктура здорового (желтого) металла; 2 - выделения свинца в микроструктуре зеркала; 3 - микроструктура серебристой поверхности с преимущественной коррозией $\alpha$-фазы

Fig. 3. Microstructure of the mirror from the burial mound Cherny Yar. 450x magnification:

1 - microstructure of uncorroded (yellow) metal; 2 - separation of lead in the microstructure of the mirror; 3 - microstructure of a silvery surface with predominant corrosion of the alpha-phase
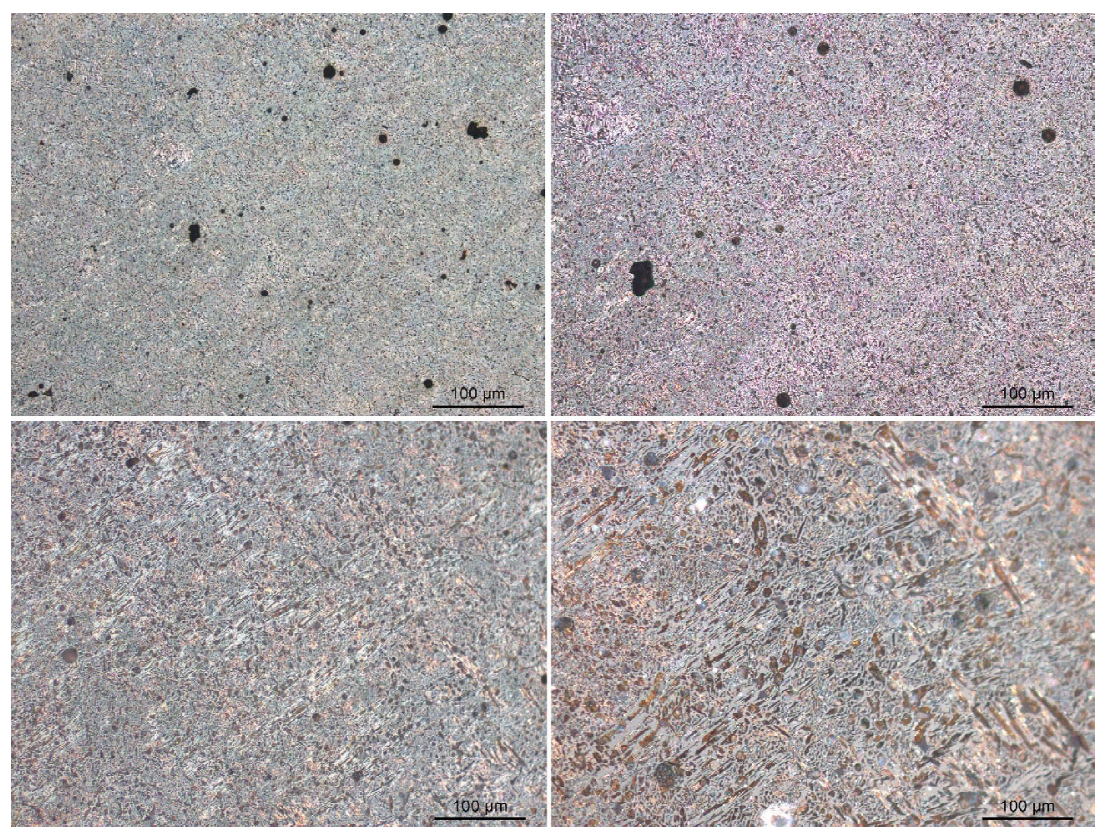

Рис. 4. Микрофотографии образца ВАЕ14 в плоском поляризованном свете

после травления хлоридом железа. Слева направо: $\times 50, \times 100, \times 200, \times 500$. Видна ярко-желтая медь в $\alpha$-фазе, окруженная серым $\alpha+\delta$ эвтектоидом. Видманштеттовые структуры видны под большим увеличением

Fig. 4. Photomicrographs of BAE14 under plain polarised light and after etching with ferric chloride:

left to right: magnifications of 50x, 100x, 200x, 500x. Bright yellow copper in alpha phase (surrounded by grey alpha + delta eutectoid) is visible. Widmanstätten structures are visible under higher magnifications 
Химический анализ состава зеркала (образца ВАE 14), приведенный ниже в таблице 2, дал следующие результаты: среднее содержание меди $72 \%$, олова 23,6 \% (вес.) и свинца $-4,3 \%$ (вес.). Свинец был добавлен для обеспечения необходимой жидкотекучести металла и придания образцу желаемой точности при изготовлении. Не исключено также, что свинец мог добавляться из эстетических соображений, поскольку присутствие этого металла меняет цвет конечного продукта, делая его более серебристым [20, p. 113, 116].

Определение состава зеркала с помощью рентгенофлуоресцентного анализа (прибор фирмы НИТОН) показало, что оно получено из сплава медь-олово-свинец, остальные элементы входят в состав примесей. В желтом металле обнаружено $23,16 \%$ олова; $6,72 \%$ свинца; $0,01 \%$ цинка; $0,03 \%$ висмута; $0,14 \%$ серебра; $0,25 \%$ сурьмы; 0,59 \% мышьяка; 0,08 \% железа; 0,06 \% никеля; 0,04 \% кобальта. В составе серебристых участков проявляется обогащение оловом (концентрация которого составляет $29 \%$ ), свинцом $(4,5 \%)$, сурьмой $(0,5 \%)$, железом $(0,2 \%)$; остальных элементов не более $0,1 \%$.

Состав и технология изготовления характерны для китайских зеркал. Как следует из литературных данных, в Китае в течение длительного времени, начиная с эпохи Воюющих царств (475 г. до н. э. -221 г. до н. э.) и вплоть до династии Тан (619-907 гг. н. э.), для получения зеркальных сплавов использовали высокооловянную бронзу со свинцом, где концентрация олова варьировалась от $18 \%$ до $26 \%$, свинца - от $1 \%$ до $9 \%$, среднее содержание этих элементов составляло: 22-25\% олова и 5-6 \% свинца [24, p. 50-62]. Концентрация олова определяет цвет зеркальных бронз, при переходе от сплавов со средним содержанием олова $22 \%$ к сплавам, в которых его среднее количество составляет $26 \%$, цвет постепенно меняется от светло-желтого до белого в бронзах с 24-26\% олова.

Выбор оловянной бронзы для изготовления зеркал не был случаен, так как этот сплав обладает сочетанием свойств, необходимых для получения хорошей зеркальной поверхности. Высокооловянные зеркальные бронзы отличаются высокой коррозионной стойкостью и большой твердостью (200-400 кГ/мм²), они прекрасно полируются. Недостатком сплавов, содержащих $20 \%$ и более олова, является их хрупкость, из-за чего многие находки фрагментированы. Введение свинца, как уже отмечено выше, улучшает литейные свойства зеркальных бронз.

Подытоживая вышеизложенное, можно отметить, что изучение зеркала методами металлографического и электронно-микроскопического анализов позволило определить, что зеркало было отлито из высокооловянной бронзы со свинцом и его дополнительной термообработки не проводилось. Эти результаты согласуются с выводами о технологии получения китайских высокооловянных бронзовых зеркал, полученными в предыдущие периоды [21, p. 113].

С точки зрения технологии изготовления данное зеркало не могло быть сделано в среде сарматской культуры, а является изделием китайского производства. Иероглифы и наличие характерного орнамента на зеркале также свидетельствуют об этом.

\section{ПРИМЕЧАНИЯ}

1 Работа выполнена при поддержке госзадания Министерства образования и науки России № 33.1389.2017/ПЧ.

Химический состав китайского зеркала из комплекса «Черный Яр»

\begin{tabular}{|l|c|c|c|}
\hline \multicolumn{1}{|c|}{ Спектр } & $\begin{array}{c}\text { Сu (медь) } \\
\text { (wt\%) }\end{array}$ & $\begin{array}{c}\text { Sn (олово) } \\
\text { (wt\%) }\end{array}$ & $\begin{array}{c}\text { Pb (свинец) } \\
\text { (wt\%) }\end{array}$ \\
\hline Участок 1 & 71,5 & 23,4 & 5,1 \\
\hline Участок 2 & 73,0 & 23,5 & 3,5 \\
\hline Участок 3 & 71,6 & 24,0 & 4,3 \\
\hline Среднее значение & $\mathbf{7 2 , 0}$ & $\mathbf{2 3 , 6}$ & $\mathbf{4 , 3}$ \\
\hline $\begin{array}{l}\text { Стандартное } \\
\text { отклонение }\end{array}$ & 0,8 & 0,3 & 0,8 \\
\hline Максимальное & 73,0 & 24,0 & 5,1 \\
\hline Минимальное & 71,5 & 23,4 & 3,5 \\
\hline
\end{tabular}


2 Определение древесины произведено доктором географических наук А.А. Гольевой. Выражаем глубокую признательность Б.А. Раеву за предоставленную информацию.

${ }^{3}$ Выражаем глубокую признательность научному сотруднику Отдела Китая Института востоковедения РАН, кандидату исторических наук С.В. Дмитриеву за лингвистическую консультацию.

${ }^{4}$ Исследование выполнено И.Г. Равич в рамках проекта, финансируемого DFG (Deutsche Forschunsggemenischaft) и РГНФ «Формы и пути культурных контактов кочевников Азиатской Сарматии. Импорты в сарматских памятниках II в. до н. э. - III в. н. э.» (FL-334/15-1) (отв. руководители: М.Ю. Трейстер и Б.А. Раев). Благодарим М.Ю. Трейстера за возможность проведения анализа.

\section{СПИСОК ЛИТЕРАТУРЫ}

1. Акбулатов, И. М. Экономика ранних кочевников Южного Урала / И. М. Акбулатов. - Уфа : Национальный музей Республики Башкортостан, 1999. - 102 c.

2. Баринова, Е. Б. Зеркала как источник по истории контактов народов Средней Азии с Китаем в древности и средневековье / Е. Б. Баринова // Вестник российского университета дружбы народов. Серия: Всеобщая история. - 2012. - № 4. C. $57-92$.

3. Гугуев, В. К. Ханьские зеркала и подражания им на территории юга Восточной Европы / В. К. Гугуев, М. Ю. Трейстер // Российская археология. - 1995. - № 3. - С. 143-156.

4. Завадская, Е. В. Философско-эстетический смысл так называемого «божественного гриба» («лин чжи») в искусстве Китая / Е. В. Завадская // Научные сообщения Государственного музея искусства народов Востока (ГМИНВ). - 1977. - № 9. С. 40-47, 171-173, 184-188.

5. Иванов, В. А. Отчет о раскопках и разведке в Оренбургской области и Башкирской АССР в 1983 году / В. А. Иванов // Архив ИА РАН. - 30 с.

6. Краева, Л. А. Отчет о раскопках курганного могильника «Черный Яр» у с. Тамар-Уткуль в Соль-Илецком районе Оренбургской области в 2007 году по Открытому листу № 395 / Л. А. Краева // Архив ИА РАН. - Т. 1. - 64 с.

7. Краева, Л. А. Отчет о раскопках курганного могильника «Черный Яр» у с. Тамар-Уткуль в Соль-Илецком районе Оренбургской области в 2007 году по Открытому листу № 395 / Л. А. Краева // Архив ИА РАН. - Т. 2. -136 с.

8. Левина, Л. М. Этнокультурная история Восточного Приаралья / Л. М. Левина. - М. : Восточная литература, 1996. - 396 с.
9. Ли Джи Ын. Китайский импорт в памятниках юга России I в. до н. э. - III в. н. э. : автореф. дис. ... канд. ист. наук / Ли ДжиЫн. - Ставрополь, 2010. - 33 с.

10. Литвинский, Б. А. Орудия и утварь из могильников Западной Ферганы / Б. А. Литвинский. М. : Наука, 1978. - 255 с.

11. Лубо-Лесниченко, Е. И. Привозные зеркала Минусинской котловины / Е. И. Лубо-Лесниченко. - М. : Наука, 1975. - 240 с.

12. Малашев, В. Ю. Позднесарматская культура Южного Приуралья во II-III вв. н. э. : автореф. дис. ... канд. ист. наук / Малашев Владимир Юрьевич. - М., 2013. -25 с.

13. Место археологического памятника в методике выделения археологического микрорайона на примере могильника «Черный Яр» (Южное Приуралье) / Л. А. Краева, Е. А. Крюкова, И. А. Шутелева, Н. Б. Щербаков // Археологические микрорайоны Северной Евразии. - Омск : Апельсин, 2009. - С. 78-82.

14. Мещеряков, Д. В. Впускные погребения сарматской культуры в курганах на реке Илек / Д. В. Мещеряков // Археологические памятники Оренбуржья. - Оренбург : ДИМУР, 1996. - С. 44-67.

15. Мошкова, М. Г. Позднесарматские материалы Лебедевского могильника в Западном Казахстане / М. Г. Мошкова // Краткие сообщения Института археологии (КСИА). - 1982. - № 170. -С. 80-87.

16. Порохова, О. И. Отчет о раскопках курганных могильников у с. Тамар-Уткуль в Соль-Илецком районе и разведке по рекам Буртя и Урта-Буртя в Оренбургской области в 1987 году по Открытому листу № 631 / О. И. Порохова // Архив ИА РАН. - 50 с.

17. Смирнов, К. Ф. Отчет о работе Чкаловской археологической экспедиции ИИМК АНСССР и Чкаловского областного музея в 1956 году / К. Ф. Смирнов // Архив ИА РАН. -64 с.

18. Смирнов, К. Ф. СарматынаИлеке/К. Ф. Смирнов. - М. : Наука, 1975. $-176 \mathrm{c}$.

19. Федотов, Г. Я. Дарите людям красоту: из практики народных художественных ремесел / Г. Я. Федотов. - М. : Просвещение, 1985 . - 255 с.

20. Experimental design of the $\mathrm{Cu}-\mathrm{As}-\mathrm{Sn}$ ternary colour diagram / M. Radivojevic, J. Pendic, A. Srejic, M. Korac, C. Davey, A. Benzonelli, M. Martinyn-Torres, N. Jovanovic and Z. Kamberovic // Journal of Archaeological Science. -2017. - Vol. 90, № 2. -P. 106119. - DOI: 10.1016/j.jas.2017.12.001.

21. Liu, Y. Scientific Analysis of the Bronze Mirrors Unearthed from the Qin Cemetery at Xinfeng, Lintong County, Shaanxi Province (in Chinese) / Y. Liu, K. H. Chen \& J. Mei // Cultural Relics of Central China. - 2015. - № 4. - P. 111-115.

22. Scott, D. A. Metallography and Microstructure of Ancient and Historic Metals / D. A. Scott. - Marina del Rey : Getty Conservation Institute, 1991. - 155 p. 
23. Scott, D. A. Copper and Bronze in Art / D. A. Scott. - Los Angeles : Getty Conservation Institute Publ., 2002. $-515 \mathrm{p}$.

24. Shokang, Z. Studies of Ancient Chinese Mirrors and other Bronze Artefacts / Z. Shokang, H. Tangkun // Metal Plating and Patination / Susan La Niece, Paul Craddock (ed.). - Oxford, 1993. - P. 50-62.

\section{REFERENCES}

1. Akbulatov I. M. Ekonomika rannikh kochevnikov Yuzhnogo Urala [Economy of the Early Nomads of the Southern Urals]. Ufa, Natsionalnyy muzey Respubliki Bashkortostan Publ., 1999. 102 p.

2. Barinova E.B. Zerkala kak istochnik po istorii kontaktov narodov Sredney Azii s Kitaem v drevnosti i srednevekovye [Mirrors as a Source of Information on the History of Contacts among the Peoples of Central Asia with China in Ancient and Medieval Times]. Vestnik rossiyskogo universiteta druzhby narodov. Seriya: Vseobshchaya istoriya [Bulletin of the Russian University of Peoples' Friendship. Series: General History], 2012, no. 4, pp. 57-92.

3. Guguev V.K., Treister M.Yu. Khanskie zerkala i podrazhaniya im na territorii yuga Vostochnoy Evropy [Han Mirrors and Their Replicas in the South of the Eastern Europe]. Rossiyskaya arkheologiya [Russian Archaeology], 1995, no. 3, pp. 143-156.

4. Zavadskaya E.V. Filosofsko-esteticheskiy smysl tak nazyvaemogo «Bozhestvennogo griba» («Linchzhi») v iskusstve Kitaya [The Philosophical and Aesthetic Sense of the So-called 'Divine Fungus' ('Lingzhi') in the Art of China]. Nauchnye soobshcheniya Gosudarstvennogo muzeya iskusstva narodov Vostoka [Reports of Museum of Oriental Art], 1977, no. 9, pp. 40-188.

5. Ivanov V.A. Otchet o raskopkakh i razvedke v Orenburgskoy oblasti i BashkirskoyASSR v 1983 godu [Report on Excavations and Exploration in the Orenburg Region and the Bashkir ASSR in 1983]. Arkhiv IA RAN [Archive of IA RAS]. Moscow, IA RAN Publ., 1983.30 p.

6. Kraeva L.A. Otchet o raskopkakh kurgannogo mogilnika «Chernyy Yar» u s. Tamar-Utkul v SolIletskom rayone Orenburgskoy oblasti v 2007 godu po Otkrytomu listu №395 [Report on the Excavation of Cherny Yar Burial Mound near the Tamar-Utkul Settlement in the Sol-Iletsky District of the Orenburg Region in 2007]. Arkhiv IA RAN [Archive of IA RAS]. Moscow, IARAN Publ., 2007, vol. 1. 64 p. (unpublished)

7. Kraeva L. A. Otchet o raskopkakh kurgannogo mogilnika «Chernyy Yar» u s. Tamar-Utkul v Sol-Iletskom rayone Orenburgskoy oblasti v 2007 godu po Otkrytomu listu №395 [Report on the Excavation of Cherniy Yar Burial Ground near Tamar-
Utkul Settlement in the Sol-Iletsky District of the Orenburg Region in 2007]. Arkhiv IA RAN [Archive of IA RAS]. Moscow, IA RAN Publ., 2007, vol. 2. 136 p. 8. Levina L.M. Etnokulturnaya istoriya Vostochnogo Priaralya [Ethnocultural History of the Eastern Cisurals]. Moscow, Vostochnaya literatura Publ., 1996.396 p.

9. Li Dzhi Yn. Kitayskiy import v pamyatnikakh yuga Rossii I v. do n.e. - III v. n.e.: avtoref. dis. ... kand. ist. nauk [Chinese Imports in the Archeological Sites of Southern Russia of the $1^{\text {st }}$ Century BC $-3^{\text {rd }}$ CenturyAD. Cand. hist. sci. abs. diss]. Stavropol, 2010. 33

10. Litvinskiy B.A. Orudiya i utvar iz mogilnikov Zapadnoy Fergany [Tools and Utensils of the Bural Grounds of Western Fergana]. Moscow, Nauka Publ., $1978.255 \mathrm{p}$.

11. Lubo-Lesnichenko E.I. Privoznye zerkala Minusinskoy kotloviny [The Imported Mirrors of the Minusinsk Hollow]. Moscow, Nauka Publ., 1975. 240 p.

12. Malashev V.Yu. Pozdnesarmatskaya kultura Yuzhnogo Priuralya vo II - III vv. n.e.: avtoref. dis. ... kand. ist. nauk [The Late Sarmatian Culture of the Southern Urals in the $2^{\text {nd }}-3^{\text {rd }} \mathrm{cc}$. AD. Cand. hist. sci. abs. diss.]. Moscow, 2013. 25 p.

13. Kraeva L.A., Kryukova E.A., Shuteleva I.A., Shcherbakov N.B. Mesto arkheologicheskogo pamyatnika v metodike vydeleniya arkheologicheskogo mikrorayona na primere mogilnika «Chernyy Yar» (Yuzhnoe Priuralye) [The Place of the Archaeological Monument in the Methodology of Allocating the Archaeological Microdistrict Based on the Example of the Cherny Yar Burial Ground (the Southern Urals)]. Arkheologicheskie mikrorayony Severnoy Evrazii [Archaeological Microdistricts of Northern Eurasia]. Omsk, Apelsin Publ., 2009, pp. 78-82.

14. Meshcheryakov D.V. Vpusknye pogrebeniya sarmatskoy kultury v kurganakh na reke Ilek [Inlet Burials of Sarmatian Culture in the Barrows on the Ilek River]. Arkheologicheskie pamyatniki Orenburzhya [Archeological Sites of the Orenburg Region]. Orenburg, DIMUR Publ., 1996, pp. 44-67.

15. Moshkova M.G. Pozdnesarmatskie materialy Lebedevskogo mogilnika v Zapadnom Kazakhstane [Late Sarmatian Findings of the Burial Ground Lebedevka in Western Kazakhstan]. Kratkie soobshcheniya Instituta arkheologii [Brief Reports of the Institute of Archaeology], 1982, no. 170, pp. 80-87.

16. Porokhova O.I. Otchet o raskopkakh kurgannykh mogilnikov u s. Tamar-Utkul v SolIletskom rayone i razvedke po rekam Burtya i UrtaBurtya v Orenburgskoy oblasti $v 1987$ godu po Otkrytomu listu № 631 [Report on Excavations of Barrows near the Tamar-Utkul Settlement in the SolIletsk Region and Exploration on the Rivers Burta and Urta-Burta in the Orenburg Region in 1987 on the 
Archaeological Excavation (Permission no. 631)]. Arkhiv IA RAN [Archive of IA RAS]. Moscow, IA RAN Publ., 1983. 50 p.

17. Smirnov K.F. Otchet o rabote Chkalovskoy arkheologicheskoy ekspeditsii IIMK AN SSSR $i$ Chkalovskogo oblastnogo muzeya v 1956 godu [Report on the Work of the Chkalov Archaeological Expedition of the Institute of History of the Academy of Sciences of the USSR and the Chkalovsky Regional Museum in 1956]. Arkhiv IA RAN [Archive of IA RAS]. Moscow, IA RAN Publ., 1956. 64 p.

18. Smirnov K.F. Sarmaty na Ileke [Sarmatians on the Ilek River]. Moscow, Nauka Publ., 1975. 176 p.

19. Fedotov G.Ya. Darite lyudyam krasotu: iz praktiki narodnykh khudozhestvennykh remesel [Give People Some Beauty: from the Practice of Folk Arts and Crafts]. Moscow, Prosveshchenie Publ., 1985. 255 p.

20. Radivojevic M., Pendiæ J., Srejic A., Korac M., Davey C., Benzonelli A., Martinón-Torres M.,
Jovanovic N., Kamberovic Z. Experimental design of the $\mathrm{Cu}$-As-Sn ternary colour diagram. Journal of Archaeological Science, 2017, vol. 90, no. 2, pp. 106119. DOI: 10.1016/j.jas.2017.12.001.

21. Liu Y., Chen K.H., Mei J. Scientific Analysis of the Bronze Mirrors Unearthed from the Qin Cemetery at Xinfeng, Lintong County, Shaanxi Province. Cultural Relics of Central China, 2015, no. 4, pp. 111115. (in Chinese)

22. Scott D.A. Metallography and Microstructure of Ancient and Historic Metals. Marina del Rey, Getty Conservation Institute, 1991. $155 \mathrm{p}$.

23. Scott D.A. Copper and Bronze in Art. Los Angeles, Getty Conservation Institute Publ., 2002. $515 \mathrm{p}$.

24. Shokang Z., Tangkun H., Studies of Ancient Chinese Mirrors and other Bronze Artefacts. Susan La Niece, Paul Craddock, eds. Metal Plating and Patination. Oxford, 1993, pp. 50-62.

\section{Information about the Authors}

Lyudmila A. Kraeva, Candidate of Sciences (History), Head of the Archaeological Museum, Orenburg State Pedagogical University, Sovetskaya St., 19, 460044 Orenburg, Russian Federation, kraeva_ludmila@mail.ru, https://orcid.org/0000-0002-6524-6998

Miljana Radivojevic, Doctor in Archaeological Science, Researcher, McDonald Institute for Archaeological Research, University of Cambridge, Downing Street, CB23ER Cambridge, United Kingdom, mr664@cam.ac.uk, https://orcid.org/0000-0001-7329-305X

Irina G. Ravich, Candidate of Science (Engineering), Leading Researcher, Metal Research Institute for Conservation, Gastello St., 44, 107014 Moscow, Russian Federation, ravich41@mail.ru, https://orcid.org/ 0000-0001-5775-8304

Larisa P. Chernikova, Candidate of Sciences (History), Senior Researcher, Institute for Oriental Studies, Russian Academy of Sciences, Rozhdestvenka St., 12, 107031 Moscow, Russian Federation, larisa-che@mail.ru, https://orcid.org/0000-0002-5207-0057

Iya A. Shuteleva, Candidate of Sciences (History), Researcher, Laboratory of Humanities Methodology, Bashkir State Pedagogical University, Oktyabrskoy revolutsii St., 3A, 450008 Ufa, Russian Federation, shutelevai@gmail.com, https://orcid.org/0000-0002-6852-5415

Nikolay B. Shcherbakov, Candidate of Sciences (History), Researcher, Laboratory of Humanities Methodology, Bashkir State Pedagogical University, Oktyabrskoy revolutsii St., 3A, 450008, Ufa, Russian Federation, sherbakov@rambler.ru, https://orcid.org/0000-0001-7731-7178

\section{Информация об авторах}

Людмила Анатольевна Краева, кандидат исторических наук, заведующий музеем археологии, Оренбургский государственный педагогический университет, ул. Советская, 19, 460044 г. Оренбург, Российская Федерация, kraeva_ludmila@mail.ru, https://orcid.org/0000-0002-6524-6998

Миляна Радивоевич, доктор археологических наук, научный сотрудник, Институт археологических исследований Макдональда, Кембриджский университет, Даунинг-стрит, CB23ER г. Кембридж, Великобритания, mr664@cam.ac.uk, https://orcid.org/0000-0001-7329-305X

Ирина Григорьевна Равич, кандидат технических наук, ведущий научный сотрудник, Государственный научно-исследовательский институт реставрации, ул. Гастелло, 44, 107114 г. Москва, Российская Федерация, ravich41@mail.ru, https://orcid.org/0000-0001-5775-8304 


\section{ДИАЛОГ «ВОСТОК - ЗАПАД»}

Лариса Петровна Черникова, кандидат исторических наук, старший научный сотрудник, Институт востоковедения РАН, ул. Рождественка, 12, 107031 г. Москва, Российская Федерация, larisa-che@mail.ru, https://orcid.org/0000-0002-5207-0057

Ия Александровна Шутелева, кандидат исторических наук, научный сотрудник лаборатории методологии и методов гуманитарных исследований, Башкирский государственный педагогический университет им. М. Акмуллы, ул. Октябрьской Революции, 3А, 450008 г. Уфа, Российская Федерация, shutelevai@gmail.com, https://orcid.org/0000-0002-6852-5415

Николай Борисович Щербаков, кандидат исторических наук, научный сотрудник лаборатории методологии и методов гуманитарных исследований, Башкирский государственный педагогический университет им. М. Акмуллы, ул. Октябрьской Революции, 3А, 450008 г. Уфа, Российская Федерация, sherbakov@rambler.ru, https://orcid.org/0000-0001-7731-7178 